\title{
Optimal Cutoff Points of Rate Pressure Product in Each Stage of Treadmill Exercise Test According to the Degree of Metabolic Syndrome in Korean Adults
}

Kyung-A Shin

Department of Clinical Laboratory Science, Shinsung University, Dangjin, Korea

\section{한국성인의 대사증후군 예방을 위한 운동부하 검사시 각 단계별 심근부담률의 적정 임계점}

신경아

신성대학교 임상병리과

The rate pressure product (RPP) is expressed as a product of the heart rate and systolic blood pressure as an index indirectly measuring the myocardial oxygen consumption, and it indicates the burden on the myocardium. The aim of this study was to determine the optimal level of RPP for preventing metabolic syndrome in a treadmill exercise test in Korean adults. Metabolic syndrome was the diagnosis of the third executive summary report on the National Cholesterol Education Program Adult Treatment Panel III (NCEP-ATP III) criteria. According to the criteria, the metabolic syndrome diagnosis group (MetS, N=25), pre-metabolic syndrome group (Pre-MetS, $\mathrm{N}=106$ ), and non-risk factor group (Non-MetS, $\mathrm{N}=65$ ) were classified. The exercise stress test was performed based on the Bruce protocol. The RPP was calculated as (heart rate $\times$ systolic blood pressure) $\div$ 1,000 . The results showed that the maximum systolic blood pressure was high despite the low daily dose reached in the diagnostic group of metabolic syndrome. The optimal threshold of the RPP at the time of the exercise treadmill test for a metabolic syndrome prediction was 12.56 $\mathrm{mmHg} \times$ beats $/ \mathrm{min} \times 10^{-3}$ in the first stage of the exercise stress test. The second stage of the exercise test was $16.94 \mathrm{mmHg} \times$ beats $/ \mathrm{min} \times 10^{-3}$, and at the third stage of the exercise test was $21.11 \mathrm{mmHg} \times$ beats $/ \mathrm{min} \times 10^{-3}$.

Key words: Cutoff points, Metabolic syndrome, Rate pressure product, Treadmill

This is an Open Access article distributed under the terms of the Creative Commons Attribution Non-Commercial License (http://creativecommons.org/licenses/by-nc/4.0) which permits unrestricted non-commercial use, distribution, and reproduction in any medium, provided the original work is properly cited.

Copyright (C 2018 The Korean Society for Clinical Laboratory Science. All rights reserved.

Corresponding author: Kyung-A Shin Department of Clinical Laboratory Science, Shinsung University, 1 Daehak-ro, Jeongmi-myeon, Dangjin 31801, Korea Tel: 82-41-350-1408

Fax: 82-41-350-1355

E-mail: mobitz2@hanmail.net

Received: March 1, 2018

Revised $1^{\text {st: }}$ March 14, 2018

Revised $2^{\text {nd }}$ : March 26, 2018

Revised 3 ${ }^{\text {rd: }}$ : April 2, 2018

Accepted: April 3, 2018
서 론

운동시 심혈관계 반응의 영향력을 알아보는 다양한 지표 중 심근산소소비량(myocardial oxygen uptake, $\mathrm{MVO}_{2}$ )은 심장 에 가해지는 부담 정도를 측정하는 지표이다[1]. 심근산소소비 량의 주요 결정 요인은 관상동맥 혈류량, 심실 수축기 압력, 심
실 용적, 질량, 수축력 및 심박수 등이다[2-5]. 심근산소소비량 을 직접 측정하기는 어렵지만, 심박수에 수축기 혈압의 곱으로 심근이 받는 부담을 나타내는 심근부담률(RPP, rate pressure product)은 심근산소소비량과 강한 상관관계를 보이고 있어 심장근육의 산소소비량, 즉 관상동맥 순환반응을 간접적으로 측정하는 지표로 이용된다 [6, 7]. 심근부담률이 증가할수록 심 
근의 에너지 효율이 떨어짐을 의미하는데, 혈압 및 심박수의 지 나친 상승을 조절하여 심근의 부담을 덜어주는 것은 심혈관계 질환을 예방하기 위해 중요하다[8,9].

관상동맥 질환자의 새벽 허혈성 심장질환 발생은 심근부담 률 상승과 밀접한 관련이 있으며, 운동시 만성적 혈압상승에 의 해 유도되는 높은 심근부담률은 부정맥 및 심근 허혈을 일으킬 수 있다[10-12]. 근육의 산소소비량은 운동에 의해 증가하게 되 는데, 이에 따라 심근의 동정맥 산소차가 증가하므로 운동 중에 는 심근이 요구하는 산소 공급을 충족시키기 위해 관상동맥 혈 류량 역시 증가한다[2]. 운동시 혈압반응은 안정시 혈압보다 고 혈압 유병률이나 심혈관 사건 발생을 예측하는데 더 유용한 지 표이며, 허리둘레와 엉덩이 둘레 같은 비만지표는 운동부하 검 사시 혈압 상승률에 영향을 미치는 위험요인으로 보고되었다 $[13,14]$. 운동부하검사중 심근부담률의 증가는 협심증 환자에 서 심근 허혈의 원인이 된다는 보고되며, 심부전 환자에서 운동 능력 저하에 의해 낮은 심근부담률을 보이는 경우 사망률이 증 가하는 부정적인 요인이 된다 $[11,12,15]$. 이와같이 운동 중 혈 압이 상승함에 따라 심근부담률이 증가하는 것은 고혈압이나 심혈관 위험요인을 보유한 질환자에게 중요한 임상적 문제를 야기할 수 있으나 이에 대한 논의는 이루어지지 않고 있다.

한편, 대사증후군은 고혈압, 고혈당, 고지혈증, 복부비만이 한 개인에게 동시에 발생하는 질환군으로서 대사증후군을 유발 하는 원인으로 인슐린 저항성이 핵심역할을 하는 것으로 알려 져 있다[16]. 또한 대사증후군은 혈액응고, 혈관내피세포 기능 이상 등 혈관성 질환을 유발하여 당뇨병 및 심혈관 질환의 위험 을 증가시키는 것으로 알려져 있다[16, 17]. 대사증후군 위험요 인은 안정시 심박수 증가 및 고혈압 발병과 관련이 있으며, 대사 증후군으로 진단받은 경우 높은 심박수와 고혈압을 동반하는 경우가 많은 것으로 알려진다[18, 19]. 이와 같이 대사증후군이 심혈관 합병증의 위험을 증가시키는 것으로 알려져 있으나, 그 기전에 관해서는 아직 명확히 밝혀진 바가 없다. 특히 안정시 높 은 심박수와 혈압반응을 보이는 대사증후군에서는 운동에 의해 높은 심근부담률을 보일 수 있기 때문에 심혈관 위험이 내제되 어 있는 대사증후군 질환자에게 운동부하검사를 통한 심근부담 률의 평가는 중요한 의미가 있다[20]. 그러므로 대사증후군에 서 운동부하 검사시 심근부담률의 적정 임계치를 제시하는 것 은 궁극적으로 당뇨병이나 심혈관 질환의 위험을 예측하기 위 한 지침을 설정하는데 근거가 될 수 있으리라 생각되지만, 대사 증후군에서 심근부담률의 효율성을 제시한 연구는 전무하다.

본 연구에서는 한국성인을 대상으로 트레드밀 운동부하 검 사시 대사증후군에서 심근부담률의 적정 수준을 제시함으로써
대사증후군 정도에 따른 심근부담률의 목표치를 설정하여 그 기준을 제시하고자 하였다.

\section{대상 및 방법}

\section{1. 연구 대상}

이 연구는 2017년 1월부터 2017년 12월까지 일개 종합병원 건강증진센터에서 종합건강검진을 실시한 20세 이상 성인 남 녀 중 운동부하검사를 받은 피험자를 대상으로 하였다. 전체 대 상자인 252명 중 고혈압, 당뇨병, 고지혈증으로 진단받아 약물 치료를 받고 있는 경우, 심박수를 조절하는 약물 복용자, 심장질 환자, 운동부하검사를 중단하였거나 연구자료에 결측치를 포 함하는 경우에 해당하는 56명을 제외한 최종 연구대상자는 196 명 이었다. 최종 대상자 중 남성 139명, 여성 57명 이었다. 진단 병력 및 약물치료 유무에 관한 자료는 자기기입식 설문지 를 통해 조사하였으며, 본 연구는 기관생명윤리위원회(institutional review board, IRB)의 심의를 받아 승인 후 연구를 수 행하였다(IRB No: SP-2017-11-009-004).

\section{2. 연구방법}

\section{1) 신체계측 및 혈압측정}

체성분 분석기 Inbody 720 (Biospace Co., Seoul, Korea)으 로 신장과 체중을 측정하였으며, 체질량지수(body mass index, $\mathrm{BMI})$ 는 체중 $(\mathrm{kg})$ 을 신장 $(\mathrm{m})$ 의 제곱으로 나눈 수치로 적 용하였다. 허리둘레 측정은 직립자세에서 줄자로 $\mathrm{WHO}$ 의 권고 방법인 갈비뼈 가장 아래 부분과 골반의 가장 높은 부분의 중간 부위를 수평으로 호기 말에 측정하였다. 수축기와 이완기 혈압 은 5 분간 안정상태에서 1 2분 간격으로 2회 측정하여 평균값 을 사용하였으며, 보정된 아네로이드 혈압계로 측정하였다.

\section{2) 대사증후군 진단기준 및 혈액분석}

대사증후군 진단은 2001년 US National Cholesterol. Education Program (NCEP)의 Adult Treatment Panel (ATP) III 에서 제시한 지침에 따라 (1)허리둘레; 남성 $>102 \mathrm{~cm}$, 여성 $>88 \mathrm{~cm}$ (2) 고중성지방혈증; 중성지방 $\geq 150 \mathrm{mg} / \mathrm{dL}$ (3) 저 $\mathrm{HDL}$-콜레스테롤혈증; 남성 $<40 \mathrm{mg} / \mathrm{dL}$, 여성 $<50 \mathrm{mg} / \mathrm{dL}$ (4) 고혈압; 수축기 혈압 $\geq 130 \mathrm{mmHg}$ 또는 이완기 혈압 $\geq 85$ $\mathrm{mmHg}$ (5)고혈당; 공복 혈당 $\geq 110 \mathrm{mg} / \mathrm{dL}$ 의 5 가지 진단기준 중 3개 이상 충족하는 경우 대사증후군 진단군(MetS)으로 정의 하였다[21]. 또한 1 2개의 기준에 해당하는 경우를 대사증후 군 전단계군(Pre-MetS), 5 개의 진단기준에 해당하지 않는 경우 
는 대사증후군 위험요인이 없는군(Non-MetS)으로 분류하였 다. 본 연구에서는 NCEP-ATP III에서 제시한 허리둘레 기준대 신 WHO 아시아/태평양지역에서 제시한 허리둘레 기준인 남성 $>90 \mathrm{~cm}$, 여성 $>80 \mathrm{~cm}$ 를 적용하여 대사증후군의 복부비만을 진단하였다[22].

혈액분석은 12 시간 이상 금식 후 상완 정중주정맥(median cubital vein)에서 채혈하여 분석하였다. 총콜레스테롤, 중성지 방, HDL (high density lipoprotein)-콜레스테롤, LDL (low density lipoprotein)-콜레스테롤, 공복혈당, 요산, 고감도 C반응단백(high sensitivity C-reactive protein, hs-CRP)항목 은 혈청분리관(serum separate tube, SST)에 채혈 후 혈청 분리 하여 TBA-200FR NEO (Toshiba, Tokyo, Japan)로 측정하였 다. 당화혈색소(hemoglobin A1c, HbA1c)는 EDTA (ethylene diamine tetra acetic acid, EDTA) tube에 채혈 후 전혈 검체로 고속액체크로마토그래피법(high performance liquid chromatography, HPLC)의 원리에 따라 Variant II (Bio Rad, CA, $\mathrm{USA}$ )로 측정하였다. 인슐린은 전기화학발광면역측정법(electrochemiluminescence immunoassay, ECLIA)의 측정원리 로 Roche Modular Analytics E170 (Roche, Mannheim, Germany)로 검사하였다.

\section{3) 운동부하검사}

운동부하검사는 운동부하검사용 트레드밀 장비(Medtrack ST 55, Quinton Instrument Co., Boston, USA)를 이용하여 3 분 간격으로 각 단계(stage)마다 회전속도와 경사도를 증가시 키는 Bruce 프로토콜을 적용하여 시행하였다[23]. 운동부하검 사 stage 1은 회전속도 $1.7 \mathrm{mile} / \mathrm{h}$, 경사도 $10 \%$, stage 2 는 회전 속도 $2.5 \mathrm{mile} / \mathrm{h}$, 경사도 $12 \%$, stage 3 은 $3.4 \mathrm{mile} / \mathrm{h}$, 경사도 $14 \%$ 로 운동부하검사를 실시하였다. 심전도는 운동직전과 운동 중 1 분 간격으로 기록하였으며, 2 분 간격으로 심박수와 혈압을 측정하였다. 정확한 혈압 측정을 위해 상완동맥 부위에 마이크 로폰이 내장된 커프를 감고 정확한 심장 박동음을 듣고 혈압을 측정하였으며, 회복기 반응을 확인하기 위해 운동부하검사 후 1 분대에 심전도, 심박수, 혈압을 측정하였다. 운동부하검사 중 심 박수와 심전도는 실시간 12채널 Quinton stress test system (Q4500, Quinton Instrument Co., Boston, USA)을 이용하여 측정하였으며, 운동부하검사는 최대 심박수인 [220-연령]의 $85 \%$ 이상 도달하는 시점까지 시행하였다. 또한 대사당량 (metabolic equivalent, MET)은 treadmill의 회전속도와 경사 도를 이용하여 다음의 공식으로 구하였다. MET=[(Speed $\times$ $0.1)+($ Grade/100 $\times 1.8 \times$ Speed $)+3.5] / 3.5$ 이다. 운동부하검
사 후 회복기는 운동을 마친 후 경사도를 $0 \%$ 로 고정하고 속도를 $1.3 \mathrm{mph}$ 로 하여 30 40초 간 트레드밀을 걷고, 트레드밀이 완 전히 멈춘 후 침대에 누워 5 분 동안 심전도, 심박수, 혈압 반응을 확인하였다. 심근부담률(rate pressure product, RPP)은 측정 된 심박수와 수축기 혈압을 통해(심박수 $\times$ 수축기 혈압) 1,000 으로 도출하였다[7]. 운동부하검사 안정시, 운동중, 회복 기 각 단계별 심근부담률의 변화율은 $\Delta \mathrm{RPP}$ 로 나타냈으며, 운 동부하검사 전 안정시 심근부담률 값을 100 으로 하였을 때 운 동부하검사 각 단계별 심근부담률 값의 변화를 백분율로 제시 하였다.

\section{3. 통계분석}

이 연구결과에서 얻어진 자료는 IBM SPSS Statistics 24.0 (IBM, NY, USA) 통계 프로그램을 사용하여 통계 처리하였다. 모든 측정형 자료는 평균과 표준편차의 기술 통계치로 표시하 였으며, 범주형 및 명목형 자료는\%로 나타냈다. 범주형 및 명목 형 자료의 대사증후군 정도에 따른 집단간 차이는 카이제곱검 정(chi-square test)을 시행하였다. 대사증후군 정도에 따른 대 상자의 임상적 특성, 운동부하검사 단계별 혈역학적 반응 및 심 근부담률의 차이를 파악하기 위해 일원변량분석(one way analysis of variance, one-way ANOVA)을 실시하였으며, 일 원변량분석 결과 유의한 차이가 나타난 경우 bonferroni 검증 방법을 이용하여 사후검증(post-hoc test, multiple comparison) 을 실시하였다. 또한 대사증후군을 예측하기 위한 심근부담률 의 적정 분별점(cutoff points)을 제시하기 위해 ROC 곡선 (receiver operating characteristic curve, ROC curve)분석 을 실시하였다. $\mathrm{ROC}$ 분석을 통해 곡선 아래의 면적(area under the curve, AUC), 민감도(sensitivity)와 특이도(specificity)를 평가하였으며, 민감도와 특이도의 합이 최대인 지점을 적정 임 계점으로 선정하였다. 이 연구의 모든 통계적 유의수준은 $P<0.05$ 로 설정하였다.

\section{결 과}

\section{1. 대사증후군 정도에 따른 연구 대상자의 임상적 특성}

대사증후군 정도에 따른 연구 대상자의 임상적 특징을 확인 한 결과 Table 1과같다. 대사증후군 정도에 따른 성별은 집단간 차이가 없었다. 연령과 체중은 대사증후군 전단계군과 대사증 후군 진단군이 대사증후군 위험요인이 없는군 보다 높았다(각 각 $P=0.004, P<0.001)$. 체질량지수, 허리둘레, 수축기와 이완 기 혈압은 대사증후군 위험요인이 없는군 보다 대사증후군 전 
Table 1. Clinical characteristics of the subject according to metabolic syndrome status

\begin{tabular}{|c|c|c|c|c|}
\hline Variable & Non-MetS (N=65) & Pre-MetS $(\mathrm{N}=106)$ & MetS $(\mathrm{N}=25)$ & $P$-value \\
\hline Men, n (\%) & $45(69.2)$ & $77(72.6)$ & $17(68.0)$ & 0.841 \\
\hline Age $(y r)$ & $44.84 \pm 10.22$ & $48.76 \pm 10.13^{\star}$ & $52.12 \pm 8.66^{*}$ & 0.004 \\
\hline Height (cm) & $166.31 \pm 8.05$ & $166.26 \pm 9.25$ & $164.81 \pm 9.20$ & 0.742 \\
\hline Weight (kg) & $62.56 \pm 9.25$ & $68.81 \pm 12.21^{*}$ & $72.94 \pm 13.78^{\star}$ & $<0.001$ \\
\hline $\mathrm{BMI}\left(\mathrm{kg} / \mathrm{m}^{2}\right)$ & $22.53 \pm 2.39$ & $24.74 \pm 2.98^{\star}$ & $26.64 \pm 3.58^{\star}, \dagger$ & $<0.001$ \\
\hline Waist circumference $(\mathrm{cm})$ & $76.31 \pm 6.74$ & $83.70 \pm 7.46^{\star}$ & $88.60 \pm 8.33^{*}$, & $<0.001$ \\
\hline Systolic BP (mmHg) & $105.76 \pm 9.96$ & $116.55 \pm 14.66^{*}$ & $126.40 \pm 17.53^{*, \dagger}$ & $<0.001$ \\
\hline Diastolic BP (mmHg) & $68.84 \pm 8.32$ & $75.81 \pm 10.30^{\star}$ & $83.60 \pm 11.94^{\star},^{\dagger}$ & $<0.001$ \\
\hline Total cholesterol (mg/dL) & $196.75 \pm 31.74$ & $203.36 \pm 35.43$ & $203.00 \pm 31.66$ & 0.444 \\
\hline $\mathrm{HDL}-\mathrm{C}(\mathrm{mg} / \mathrm{dL})$ & $60.66 \pm 13.10$ & $49.03 \pm 10.64^{*}$ & $43.16 \pm 10.61^{*}$ & $<0.001$ \\
\hline $\mathrm{LDL}-\mathrm{C}(\mathrm{mg} / \mathrm{dL})$ & $122.15 \pm 30.52$ & $132.69 \pm 31.13$ & $127.56 \pm 31.31$ & 0.098 \\
\hline Triglyceride (mg/dL) & $87.69 \pm 32.36$ & $141.92 \pm 76.66^{\star}$ & $234.08 \pm 125.23^{*}+$ & $<0.001$ \\
\hline Fasting glucose (mg/dL) & $88.81 \pm 7.99$ & $95.66 \pm 17.73^{\star}$ & $110.28 \pm 22.49^{*, \dagger}$ & $<0.001$ \\
\hline $\mathrm{HbA} 1 \mathrm{c}(\%)$ & $5.49 \pm 0.30$ & $5.86 \pm 0.66^{\star}$ & $6.32 \pm 0.77^{*}{ }^{\dagger}$ & $<0.001$ \\
\hline Insulin (uU/mL) & $4.63 \pm 2.92$ & $6.65 \pm 3.70^{*}$ & $8.89 \pm 5.56^{*}+$ & $<0.001$ \\
\hline Uric acid (mg/dL) & $5.23 \pm 1.43$ & $5.60 \pm 1.38$ & $5.63 \pm 1.44$ & 0.215 \\
\hline hs-CRP (mg/dL) & $0.23 \pm 0.64$ & $0.20 \pm 0.62$ & $0.21 \pm 0.20$ & 0.957 \\
\hline
\end{tabular}

Calculated by one-way ANOVA and chi-square test.

Values are presented as mean \pm SD and number $(\%)$.

*Significantly different from the Non-MetS at $P<0.05,{ }^{\dagger}$ Significantly different from Pre-MetS at $P<0.05$.

Abbreviations: MetS, metabolic syndrome; BMI, body mass index; SBP, systolic blood pressure; DBP, diastolic blood pressure; HDL-C, high density lipoprotein cholesterol; LDL-C, low density lipoprotein cholesterol; HbA1c, hemoglobin A1c; hs-CRP, high sensitivity C-reactive protein.

Table 2. Comparison of the hemodynamic response during treadmill exercise test by metabolic syndrome status

\begin{tabular}{|c|c|c|c|c|}
\hline Variable & Non-MetS (N=65) & Pre-MetS $(\mathrm{N}=106)$ & MetS $(\mathrm{N}=25)$ & $P$-value \\
\hline Supine HR (beats/min) & $62.10 \pm 9.95$ & $62.83 \pm 10.68$ & $65.60 \pm 10.44$ & 0.360 \\
\hline Supine SBP (mmHg) & $114.29 \pm 13.19$ & $121.04 \pm 14.68^{\star}$ & $131.04 \pm 17.74^{* \dagger}$ & $<0.001$ \\
\hline Supine DBP $(\mathrm{mmHg})$ & $70.38 \pm 9.13$ & $76.76 \pm 11.53^{\star}$ & $84.28 \pm 12.87^{*}{ }^{\dagger}$ & $<0.001$ \\
\hline Stage 1 HR (beats/min) & $100.24 \pm 12.18$ & $105.27 \pm 15.83$ & $106.80 \pm 10.87$ & 0.054 \\
\hline Stage 1 SBP $(\mathrm{mmHg})$ & $127.66 \pm 16.29$ & $135.66 \pm 21.80^{*}$ & $143.04 \pm 22.12^{\star}$ & 0.003 \\
\hline Stage 1 DBP $(\mathrm{mmHg})$ & $71.44 \pm 10.02$ & $78.96 \pm 13.19^{\star}$ & $84.00 \pm 15.74^{\star}$ & $<0.001$ \\
\hline Stage 2 HR (beats/min) & $119.78 \pm 16.07$ & $120.74 \pm 15.01$ & $123.68 \pm 11.29$ & 0.543 \\
\hline Stage 2 SBP $(\mathrm{mmHg})$ & $137.24 \pm 16.53$ & $145.50 \pm 21.35^{*}$ & $156.04 \pm 23.20^{\star}$ & $<0.001$ \\
\hline Stage 2 DBP $(\mathrm{mmHg})$ & $71.24 \pm 9.65$ & $78.66 \pm 12.66^{*}$ & $85.76 \pm 15.93^{*, \dagger}$ & $<0.001$ \\
\hline Stage 3 HR (beats/min) & $142.01 \pm 18.30$ & $141.99 \pm 17.86$ & $142.54 \pm 13.48$ & 0.990 \\
\hline Stage 3 SBP $(\mathrm{mmHg})$ & $148.54 \pm 17.01$ & $156.60 \pm 23.10$ & $169.66 \pm 22.13^{*, \dagger}$ & $<0.001$ \\
\hline Stage 3 DBP (mmHg) & $74.32 \pm 10.55$ & $79.75 \pm 11.49^{\star}$ & $85.62 \pm 14.03^{*}$ & $<0.001$ \\
\hline Max HR (beats/min) & $165.92 \pm 12.54$ & $159.12 \pm 17.69^{\star}$ & $153.68 \pm 12.84^{*}$ & 0.002 \\
\hline Max SBP $(\mathrm{mmHg})$ & $159.68 \pm 18.47$ & $166.72 \pm 21.98$ & $176.96 \pm 22.53^{*}$ & 0.002 \\
\hline Max DBP $(\mathrm{mmHg})$ & $77.09 \pm 9.81$ & $82.10 \pm 11.85^{\star}$ & $87.56 \pm 14.59^{\star}$ & $<0.001$ \\
\hline Recovery 1 min HR (beats/min) & $130.00 \pm 16.36$ & $127.06 \pm 19.32$ & $127.20 \pm 14.11$ & 0.561 \\
\hline Recovery 1 min SBP(mmHg) & $133.62 \pm 25.32$ & $152.38 \pm 24.56^{\star}$ & $151.11 \pm 24.58^{\star}$ & $<0.001$ \\
\hline Recovery 1 min DBP(mmHg) & $69.72 \pm 12.70$ & $77.85 \pm 14.58^{\star}$ & $80.00 \pm 14.05^{\star}$ & 0.002 \\
\hline Exercise duration (min) & $10.30 \pm 1.42$ & $9.53 \pm 1.96^{*}$ & $8.67 \pm 1.74^{\star}$ & $<0.001$ \\
\hline Exercise capacity (MET) & $12.33 \pm 1.69$ & $11.54 \pm 2.11^{\star}$ & $10.50 \pm 1.99^{\star}$ & $<0.001$ \\
\hline
\end{tabular}

Calculated by one-way ANOVA.

Values are presented as mean $\pm \mathrm{SD}$.

*Significantly different from the Non-MetS at $P<0.05,{ }^{\dagger}$ Significantly different from Pre-MetS at $P<0.05$.

Abbreviations: MetS, metabolic syndrome; HR, heat rate; SBP, systolic blood pressure; DBP, diastolic blood pressure; MET, metabolic equivalent. 
단계군과 대사증후군 진단군이 높았으며, 대사증후군 진단군 은 대사증후군 전단계군 보다 높았다(각각 $P<0.001$ ). 혈액학 적 변인 중 $\mathrm{HDL}$-콜레스테롤은 대사증후군 위험요인이 없는군 보다 대사증후군 전단계군과 대사증후군 진단군에서 낮게 나타 났다 $(P<0.001)$. 중성지방, 공복혈당, $\mathrm{HbA1c}$, 인슐린은 대사 증후군 전단계군과 대사증후군 진단군에서 대사증후군 위험요 인이 없는군 보다 높게 나타났으며, 대사증후군 진단군은 대사 증후군 전단계군 보다 높았다(각각 $P<0.001$ ). 그러나 LDL-콜 레스테롤, 요산, hs-CRP는 대사증후군 정도에 따른 집단간 차 이는 없었다.

\section{2. 대사증후군 정도에 따른 운동부하검사 단계별 혈역학적 반응의 차이}

대사증후군 정도에 따른 운동부하검사 각 단계별 혈역학적 반응의 차이를 확인한 결과 Table 2에 제시된 바와 같다. 대사증 후군 정도에 따른 안정시 심박수, 운동부하검사 1단계 심박수, 운동부하검사 2단계 심박수 및 운동부하검사 3단계 심박수는 집단간 차이가 없었다. 안정시 수축기와 이완기 혈압은 대사증 후군 진단군과 대사증후군 전단계군이 대사증후군 위험요인이 없는군 보다 높았으며, 대사증후군 진단군은 대사증후군 전단 계군 보다 높았다(각각 $P<0.001$ ). 운동부하검사 1 단계에서의 수축기와 이완기 혈압은 대사증후군 위험요인이 없는군 보다 대사증후군 전단계군과 대사증후군 진단군이 높았다(각각 $P=0.003, P<0.001)$. 운동부하검사 2 단계에서의 수축기와 이 완기 혈압은 대사증후군 위험요인이 없는군 보다 대사증후군 전단계군과 대사증후군 진단군에서 높았으며, 이완기 혈압은 대사증후군 진단군이 대사증후군 전단계군 보다도 높았다(각 각 $P<0.001$ ). 운동부하검사 최대 심박수와 최대 이완기 혈압은 대사증후군 전단계군과 대사증후군 진단군이 대사증후군 위험
요인이 없는군 보다 높았다(각각 $P=0.002, P<0.001$ ). 또한 운 동부하검사 최대 수축기 혈압은 대사증후군 위험요인이 없는군 과 대사증후군 전단계군 보다 대사증후군 진단군에서 높았다 $(P=0.002)$. 운동부하검사 후 1 분대의 수축기와 이완기 혈압은 대사증후군 위험요인이 없는군 보다 대사증후군 전단계군과 대 사증후군 진단군이 높았으며(각각 $P<0.001, P=0.002$ ), 운동 부하검사 후 회복기 1 분대의 심박수는 집단간 차이가 없었다. 운동능력을 나타내는 운동시간과 대사당량은 대사증후군 위험 요인이 없는군 보다 대사증후군 전단계군과 대사증후군 진단군 에서 낮게 나타났다(각각 $P<0.001$ ).

\section{3. 대사증후군 정도에 따른 운동부하검사 단계별 심근부담률의 차이}

대사증후군 정도에 따른 운동부하검사 각 단계별 심근부담 률의 차이를 확인한 결과 안정시 심근부담률은 대사증후군 위 험요인이 없는군 보다 대사증후군 진단군이 높았으며, 대사증 후군 진단군은 대사증후군 전단계군 보다도 높았다 $(P<0.001)$. 운동부하검사 1 단계에서의 심근부담률은 대사증후군 위험요 인이 없는군 보다 대사증후군 전단계군과 대사증후군 진단군에 서 높았다 $(P=0.001)$. 운동부하검사 2단계와 3 단계에서의 심근 부담률은 대사증후군 진단군에서 대사증후군 위험요인이 없는 군과 대사증후군 전단계군 보다 높게 나타났다(각각 $P=0.002$, $P=0.010)$. 그러나 최대 운동시 심근부담률은 대사증후군 정도 에 따라 차이가 없었다. 또한 운동부하검사각 단계별 심근부담 률의 변화율은 대사증후군 정도에 따른 집단간 차이가 없었다 (Table 3).

Table 3. Comparison of the RPP response during treadmill exercise test by metabolic syndrome status

\begin{tabular}{|c|c|c|c|c|}
\hline Variable & Non-MetS $(\mathrm{N}=65)$ & Pre-MetS $(\mathrm{N}=106)$ & MetS $(N=25)$ & $P$-Value \\
\hline Supine RPP $\left(\mathrm{mmHg} \times\right.$ beats $\left./ \mathrm{min} \times 10^{-3}\right)$ & $7.08 \pm 1.29$ & $7.62 \pm 1.69$ & $8.65 \pm 2.12^{*, \dagger}$ & $<0.001$ \\
\hline Stage $1 \mathrm{RPP}\left(\mathrm{mmHg} \times\right.$ beats $\left./ \mathrm{min} \times 10^{-3}\right)$ & $12.79 \pm 2.29$ & $14.38 \pm 3.72^{*}$ & $15.40 \pm 3.51^{*}$ & 0.001 \\
\hline Stage 2 RPP $\left(\mathrm{mmHg} \times\right.$ beats $\left./ \mathrm{min} \times 10^{-3}\right)$ & $16.46 \pm 3.10$ & $17.64 \pm 3.81$ & $19.41 \pm 4.12^{\star}$ & 0.002 \\
\hline Stage 3 RPP $\left(\mathrm{mmHg} \times\right.$ beats $\left./ \mathrm{min} \times 10^{-3}\right)$ & $21.10 \pm 3.63$ & $22.32 \pm 4.73$ & $24.30 \pm 4.90^{*}$ & 0.010 \\
\hline Max RPP $\left(\mathrm{mmHg} \times\right.$ beats $\left./ \mathrm{min} \times 10^{-3}\right)$ & $26.49 \pm 4.07$ & $26.47 \pm 4.12$ & $27.25 \pm 4.69$ & 0.692 \\
\hline$\Delta$ stage 1 RPP $(\%)$ & $183.41 \pm 31.15$ & $191.54 \pm 42.42$ & $182.13 \pm 37.39$ & 0.304 \\
\hline$\Delta$ stage 2 RPP (\%) & $235.91 \pm 42.69$ & $238.26 \pm 53.86$ & $231.58 \pm 54.15$ & 0.830 \\
\hline$\Delta$ stage 3 RPP (\%) & $302.64 \pm 53.34$ & $302.72 \pm 75.66$ & $295.48 \pm 72.36$ & 0.891 \\
\hline$\Delta \operatorname{Max} \operatorname{RPP}(\%)$ & $383.91 \pm 73.82$ & $359.75 \pm 82.88$ & $329.65 \pm 83.85^{\star}$ & 0.013 \\
\hline
\end{tabular}

Calculated by one-way ANOVA.

Values are presented as mean \pm SD.

*Significantly different from the Non-MetS at $P<0.05,{ }^{\dagger}$ Significantly different from Pre-MetS at $P<0.05$.

Abbreviations: RPP, rate pressure products; MetS, metabolic syndrome. 
Table 4. Cutoff points of RPP response during treadmill exercise test with metabolic syndrome

\begin{tabular}{cccccc}
\hline Variable & Cutoff points & Sensitivity & Specificity & (95\% confidence interval) & $P$-value \\
\hline Supine RPP & 8.47 & $45.8 \%$ & $83.0 \%$ & $0.668(0.556 \sim 0.779)$ & 0.008 \\
Stage 1 RPP & 12.56 & $83.3 \%$ & $47.3 \%$ & $0.663(0.546 \sim 0.781)$ & 0.010 \\
Stage 2 RPP & 16.94 & $75.0 \%$ & $58.2 \%$ & $0.668(0.562 \sim 0.775)$ & 0.008 \\
Stage 3 RPP & 21.11 & $79.2 \%$ & $49.7 \%$ & $0.648(0.546 \sim 0.751)$ & 0.019 \\
\hline
\end{tabular}

Abbreviations: AUC, area under the curve; RPP, rate pressure.

\section{4. 대사증후군을 예측하기 위한 운동부하검사 단계별 적정 심근부담률}

$\mathrm{ROC}$ 분석으로 대사증후군 예측을 위한 운동부하검사 각 단 계별 적정 심근부담률은 Table 4에 제시된 바와같다. 대사증후 군 예측을 위한 안정시 심근부담률의 $\mathrm{AUC}$ 값은 0.668 , 운동부 하검사 1 단계에서의 심근부담률의 $\mathrm{AUC}$ 값은 0.663 , 운동부하 검사 2단계의 심근부담률의 $\mathrm{AUC}$ 값은 0.668 , 운동부하검사 3 단계의 심근부담률의 $\mathrm{AUC}$ 값은 0.648로 나타났다. 또한 대사 증후군 예측을 위한 안정시 심근부담률의 적정 임계점은 8.47 $\mathrm{mmHg} \times$ beats $/ \mathrm{min} \times 10^{-3}$, 민감도는 $45.8 \%$, 특이도는 $83.0 \%$ 으로 나타났다 $(P=0.008)$. 대사증후군 예측을 위한 운동부하검 사 1 단계의 심근부담률의 적정 임계점은 $12.56 \mathrm{mmHg} \times$ beats $/ \mathrm{min} \times 10^{-3}$, 민감도는 $83.3 \%$, 특이도는 $47.3 \%$ 였다 $(P=0.010)$. 대사증후군 예측을 위한 운동부하검사 2 단계의 심 근부담률의 적정 임계점은 $16.94 \mathrm{mmHg} \times$ beats $/ \mathrm{min} \times 10^{-3}$, 민감도는 $75.0 \%$, 특이도는 $58.2 \%$ 였다 $(P=0.008)$. 또한 대사증 후군 예측을 위한 운동부하검사 3 단계에서의 심근부담률의 적 정 임계점은 $21.11 \mathrm{mmHg} \times$ beats $/ \mathrm{min} \times 10^{-3}$ 이며, 민감도는 $79.2 \%$, 특이도는 $49.7 \%$ 로 나타났다 $(P=0.019)$.

\section{고 찰}

본 연구는 운동부하 검사시 각 단계별 대사증후군에 따른 심 근부담률의 적정 임계점을 제시하고자 하였다.

심근산소소비량 $\left(\mathrm{MVO}_{2}\right)$ 은 증가된 심근산소요구량에 대한 관상동맥 순환반응의 좋은 지표이다[24]. 일상적으로 임상에서 심근산소소비량의 직접 측정이 어렵지만 박출작업량(stroke work), 용질확산법칙(Fick principle), 장력시간계수(tension time index) 및 심근부담률(rate pressure product, RPP)과 같 은 간접적인 방법으로 산출 가능하다[25]. 특히 심박수와 수축 기 혈압의 곱으로 쉽게 측정할 수 있는 지표인 심근부담률은 심 근산소소비량의 직접 측정법과 높은 상관성을 보이며 심근대사 요구에 대한 관상동맥 순환반응과 더불어 혈류량 증가를 잘 정
의하고 있다[7, 26]. 심박수와 수축기 혈압은 모두 안정시와 운 동 중에 심근산소소비의 변화를 결정하는 가장 중요한 변수이 며, 심근부담률은 운동 중 활동 심근에 적절한 혈액을 공급하기 위해 심장의 작업 부하와 교감신경유출(sympathetic nerve discharge) 증가로 운동시 증가한다[27].

일반적으로 운동부하 검사시 미국심장협회에서 제시한 [220-연령]의 $85 \%$ 이상 도달하는 시점으로 최대 심박수 또는 최대 운동강도를 예측하는데 사용하고 있으나[28], 이는 심박 수 만을 고려한 경우로 심박수에 영향을 미치는 베타차단제와 같은 약물 복용자에게 적용이 어려워 심박수와 더불어 수축기 혈압 상승을 고려한 심근부담률을 활용할 필요성이 있겠다 [29]. 협심증 환자의 경우 심박수와 수축기 혈압 상승에 따른 심 근부담률의 상승은 심근 허혈을 일으키는 원인이며, 베타차단 제와 같은 약물에 의해 심박수와 수축기 혈압을 낮추게 되면 협 심증 예방에 도움이 되는 것으로 알려져 있다[11, 12,30$]$.

본 연구결과에서 대사증후군 진단군은 도달한 일량이 낮음 에도 불구하고 최대 수축기 혈압이 높은 것으로 나타났으며, 이 러한 요인은 말초동맥의 확장기능장애로 인한 후부하상승으로 다른 집단보다 과도한 혈압상승을 보이기 때문으로 생각된다. 따라서 대사증후군 진단군에서 운동시 운동강도를 설정할 때 대사증후군 위험요인이 없는 집단보다 운동에 의해 높은 혈압 상승을 보이므로 수축기 혈압상승을 고려하여야 하겠다.

심근부담률은 운동이 진행됨에 따라 점진적으로 증가하는데 관상동맥질환을 동반한 폐경 전 여성에서 최대 심근부담률은 $27 \pm 1.0 \mathrm{mmHg} \times$ beats $/ \mathrm{min} \times 10^{-3}$ 이며, 폐경기 여성은 $25 \pm$ $1.0 \mathrm{mmHg} \times$ beats $/ \mathrm{min} \times 10^{-3}$ 으로 관상동맥질환을 동반한 폐 경기 여성에서 낮은 심근부담률을 보였다[24]. 최대 심근부담 률은 심장의 심근산소요구량과 심장의 부하를 정확하게 반영하 는 지표이며, 허혈성 심질환자에게서 심근부담률이 $25 \mathrm{mmHg} \times$ beats $/ \min \times 10^{-3}$ 를 초과하는 경우는 드문 것으로 보고된다[24].

본 연구에서는 성인을 대상으로 운동부하 검사시 대사증후 군 예방을 위한 적정 심근부담률의 임계점은 운동부하검사 1 단 계에서 $12.56 \mathrm{mmHg} \times$ beats $/ \mathrm{min} \times 10^{-3}$, 운동부하검사 2 단계 는 $16.94 \mathrm{mmHg} \times$ beats $/ \mathrm{min} \times 10^{-3}$, 운동부하검사 3 단계에서 
는 $21.11 \mathrm{mmHg} \times$ beats $/ \mathrm{min} \times 10^{-3}$ 로 나타났다. 심박수의 변 화 없이 혈압의 증가는 혈압의 증가와 함께 심박수가 증가하는 경우보다 심근 산소화(myocardial oxygenation)에 더 유익한 것으로 보고된다[26]. 심근부담률의 임계치에 대한 선행연구 중 Fornitano와 Godoy [31]의 연구에 따르면 최대 운동시 30 $\mathrm{mmHg} \times$ beats $/ \mathrm{min} \times 10^{-3}$ 이상의 심근부담률을 나타내는 경 우 폐쇄성 관상동맥 질환을 예측하는 유용한 도구가 될 수 있음 을 입증하였다. 안정시 심근부담률은 7-9 mmHg $\times$ beats/ $\min \times 10^{-3}$ 정도이며, 심근부담률이 $10 \mathrm{mmHg} \times$ beats $/ \mathrm{min} \times$ $10^{-3}$ 이상이면 심장질환의 위험이 증가하는 명확한 지표라는 결 과가 제시된다[25, 32]. 그러나 운동에 의한 심근부담률이 22 $\mathrm{mmHg} \times$ beats $/ \mathrm{min} \times 10^{-3}$ 이상이면 심근 허혈과 협심증의 위 험이 증가하는 것으로 간주된다[32]. 그러므로 White [6]에 의 하면 건강인에서 심박수가 60 120 bpm이고 수축기 혈압이 $100 \sim 140 \mathrm{mmHg}$, 심근부담률은 $12 \mathrm{mmHg} \times$ beats $/ \mathrm{min} \times 10^{-3}$ 이하이면 심혈관 합병증 위험이 없는 것으로 간주된다고 보고 하였다. 대사증후군 예측을 위한 심근부담률의 적정 기준치를 확인한 선행연구가 없어 비교는 어려우나, 운동부하 검사시 각 단계별로 본 연구에서 정량화하여 제시한 심근부담률의 임계치 를 적용하는 것은 심혈관계 위험요인들이 군집해서 나타나는 대사증후군의 예방을 위한 지침을 설정하는데 기준이 될 수 있 을 것으로 생각된다.

심근부담률에 대한 선행연구에 따르면, 비만 정도가 심해질 수록 안정시, 운동시, 회복기 심근부담률이 증가하며, 유산소 운 동은 심근부담률을 감소시키는 효과가 있었다[33, 34]. 또한 만 성 안정형 협심증 환자에게서 지속적인 유산소 운동을 통해 같 은 운동강도에서 심근부담률을 감소시켰으며, 이로 인해 협심 증 발생을 낮추는 효과를 확인하였다[35]. 관상동맥 질환자의 경우 심근부담률이 증가할수록 허혈 발생 가능성이 증가하는 반면, 체력적으로 매우 허약한 심혈관 질환자에게서 지속적인 운동으로 최대 심근부담률이 증가하였다면 이는 심근이 부하된 운동량을 견디면서 일할 수 있는 능력이 향상되었다는 긍정적 인 결과로 해석된다[11, 12,36].

본 연구는 운동부하 검사시 대사증후군에 따른 각 단계별 심 근부담률의 적정 임계점을 추정하여 제시하고자 하였으나, 일 부 민감도와 특이도가가 낮아 진단적 선별검사의 기준으로서 제한점이 있다. 또한 대사증후군 정도에 따른 집단간 연령에 차 이를 보이고 있으나 이를 통제하지 않은 점에서 결과해석에 주 의를 요한다. 그럼에도 불구하고 이 연구는 한국의 성인남녀를 대상으로 대사증후군에 따른 운동부하 검사시 심근부담률의 목 표치를 제시하였다는데 의미가 있을 것으로 판단되며, 향후 다
양한 연령별, 성별에 따른 심근부담률의 임계치를 제시하는 연 구가 필요하리라 생각된다.

\section{요 약}

심근부담률은 심근산소소비량을 간접적으로 측정하는 지표 로 심박수와수축기 혈압의 곱으로 나타내며, 심근이 받는 부담 을 나타낸다. 본 연구는 한국성인을 대상으로 트레드밀 운동부 하 검사시 대사증후군에 따른 심근부담률의 적정 수준을 제시 함으로써 대사증후군 유병률을 낮추기 위한 심근부담률의 목표 치를 설정하여 그 기준을 제시하고자 하였다. 대사증후군 진단 은 National Cholesterol Education Program (NCEP)의 Adult Treatment Panel (ATP) III에서 제시한 5가지 진단기준 중 3 개 이상 충족하는 경우 대사증후군 진단군(MetS, $\mathrm{N}=25$ ), $1 \sim 2$ 개의 기준에 해당하는 경우를 대사증후군 전단계군 (Pre-MetS, N=106), 5개의 진단기준에 해당하지 않는 경우는 대사증후군 위험요인이 없는군(Non-MetS, N=65)으로 분류하 였다. 운동부하검사는 Bruce 프로토콜에 따라 시행하였다. 심 근부담률은(심박수 $\times$ 수축기 혈압) $\div 1,000$ 으로 구하였다. 본 연구결과 대사증후군 진단군에서 도달한 일량이 낮음에도 불구 하고 최대 수축기 혈압이 높은 것으로 나타났다. 또한 대사증후 군에 따른 운동부하 검사시 심근부담률의 최적 임계점은 운동 부하검사 1 단계에서는 $12.56 \mathrm{mmHg} \times$ beats $/ \mathrm{min} \times 10^{-3}$, 운동 부하검사 2 단계는 $16.94 \mathrm{mmHg} \times$ beats $/ \mathrm{min} \times 10^{-3}$, 운동부하 검사 3 단계에서는 $21.11 \mathrm{mmHg} \times$ beats $/ \mathrm{min} \times 10^{-3}$ 로 나타났다.

\section{Acknowledgements: None}

Conflict of interest: None

\section{REFERENCES}

1. Jin SM, Shin SY, Kim WJ. The effects of 12-weeks' intermittent high-intensity exercise on the myocardial oxygen uptake and pulse wave velocity. Journal of Wellness. 2017;12:689-698.

2. Cheitlin MD, Sokolow M. Clinical cardiology. Norwalk: Appleton and Lange; 1993. p1-38.

3. Detollenaere M, Duprez D, De Buyzere M, Vandekerckhove H, De Cock N, De Backer G. Myocardial oxygen demands of job activities in post-myocardial infarct patients. Eur Heart J. 1993;14:373-376.

4. Meyer K, Samek L, Pinchas A, Baier M, Betz P, Roskamm H. Relationship between ventilatory threshold and onset of ischaemia in ECG during stress testing. Eur Heart J. 1995; 16:623-630.

5. Ridocci F, Velasco JA, Echánove I, Soriano G, Cruz Torregrosa 
M, Payá R, et al. Effects of a 1-year exercise training program on myocardial ischemia in patients after myocardial infarction. Cardiology. 1992;80:406-412.

6. White WB. Heart rate and the rate-pressure product as determinants of cardiovascular risk in patients with hypertension. Am J Hypertens. 1999;12(2 Pt 2):50-55.

7. Gobel FL, Norstrom LA, Nelson RR, Jorgensen CR, Wang Y. The rate-pressure product as an index of myocardial oxygen consumption during exercise in patients with angina pectoris. Circulation. 1978;57:549-556.

8. Kim YJ, Kim C, Ahn JK, Lim SW, Kim EK, Shin YO, et al. Comparison of myocardial oxygen uptake and blood pressure in myocardial infarction patients response to treadmill and bike exercise therapy. Korean J Sports Med. 2002;20: 15-21.

9. Pizzi J, Silva LR, Moser D, Leite N. Relationship between subclinical atherosclerosis, blood pressure, and lipid profile in obese children and adolescents: a systematic review. Arq Bras Endocrinol Metabol. 2013;57:1-6.

10. Deedwania PC, Nelson JR. Pathophysiology of silent myocardial ischemia during daily life. Hemodynamic evaluation by simultaneous electrocardiographic and blood pressure monitoring. Circulation. 1990;82:1296-1304.

11. Kim C, Kim CH, Jee H, Lim YJ, Kim YJ. Effects of exercise type on hemodynamic responses and cardiac events in ACS patients. J Phys Ther Sci. 2014;26:609-614.

12. Kim YJ, Kim CH, Park KM. Excessive exercise habits of runners as new signs of hypertension and arrhythmia. Int J Cardiol. 2016;217:80-84.

13. Filipovský J, Ducimetière P, Safar ME. Prognostic significance of exercise blood pressure and heart rate in middle-aged men. Hypertension. 1992;20:333-339.

14. Shin KA. The blood pressure response during graded exercise test in obese adults. Biomed Sci Letters. 2017;23:215-222

15. Fornitano LD, Godoy MF. Increased rate-pressure product as predictor for the absence of significant obstructive coronary artery disease in patients with positive exercise test. Arq Bras Cardiol. 2006;86:138-144.

16. Isomaa $B$, Almgren $P$, Tuomi T, Forsén B, Lahti K, Nissén M, et al. Cardiovascular morbidity and mortality associated with the metabolic syndrome. Diabetes Care. 2001;24:683-689.

17. Isomaa B. A major health hazard: the metabolic syndrome. Life Sci. 2003;73:2395-2411.

18. Ishizaka $\mathrm{N}$, Ishizaka $\mathrm{Y}$, Toda $\mathrm{E}$, Nagai $\mathrm{R}$, Yamakado $\mathrm{M}$. Association between serum uric acid, metabolic syndrome, and carotid atherosclerosis in Japanese individuals. Arterioscler Thromb Vasc Biol. 2005;25:1038-1044.

19. Shin KA. Association between resting heart rate and risk factors of metabolic syndrome in Korean men. Journal of Wellness. 2015;10:305-316.

20. Rossi AM, Davies E, Lavoie KL, Arsenault A, Gordon JL, Meloche $\mathrm{B}$, et al. The impact of metabolic syndrome and endothelial dysfunction on exercise-induced cardiovascular changes. Obesity (Silver Spring). 2013;21:143-148.

21. Expert panel on detection, evaluation, and treatment of high blood cholesterol in adults. Executive summary of the third report of the national cholesterol education program (NCEP) ex- pert panel on detection, evaluation, and treatment of high blood cholesterol in adults (Adult Treatment Panel III). JAMA. 2001;285:2486-2497.

22. World Health Organization. The Asia-Pacific Perspective: Redefining obesity and its treatment. Sydney, Australia: health communications Australia; 2000. p19-20.

23. Bruce RA, Blackmon JR, Jones JW, Strait G. Exercising testing in adult normal subjects and cardiac patients. Pediatrics. 1963; 32:742-756.

24. Nagpal S, Walia L, Lata H, Sood N, Ahuja GK. Effect of exercise on rate pressure product in premenopausal and postmenopausal women with coronary artery disease. Indian J Physiol Pharmacol. 2007;51:279-283.

25. Sarnoff SJ, Braunwald E, Welch GH Jr, Case RB, Stainsby WN, Macruz R. Hemodynamic determinants of oxygen consumption of the heart with special reference to the tension-time index. Am J Physiol. 1958;192:148-156.

26. Zargar JA, Naqash IA, Gurcoo SA, Mehraj-Ud-Din. Comparative evaluation of the effect of metoprolol and esmolol on rate pressure product and ECG changes during laryngoscopy and endotracheal intubation in controlled hypertensive patients. Indian J Anaesth. 2002;46:365-368.

27. Ellestad MH. Stress testing. 4th ed. New Delhi: Jaypee Brothers; 1996. p17, 379.

28. Londeree BR. Moeschberger ML. Influence of age and other factors on maximal heart rate. J Cardiopulm Rehabil. 1984;4:44-49.

29. Kwon MG, Kim YJ. Study on the application of exercise type in exercise intensity setting. Korean Journal of Sport. 2017;15: 947-955.

30. ACSM. Exercise management for persons with chronic disease and disabilities. 2nd ed. Indianapolis: American College of Sports Medicine; 2003. p88.

31. Fornitano LD, Godoy MF. Increased rate-pressure product as predictor for the absence of significant obstructive coronary artery disease in patients with positive exercise test. Arq Bras Cardiol. 2006;86:138-144.

32. Fletcher GF, Cantwell JD, Watt EW. Oxygen consumption and hemodynamic response of exercises used in training of patients with recent myocardial infarction. Circulation. 1979;60: 140-144.

33. Lee HJ, Park YJ, Kim YK, Han KS, Jin YS. The effects of exercise training on body composition, MVO and QTc interval in obese woman. Korean J Sports Med. 1999;17:188-196.

34. Kim NI, Kim YI, Choi KS, Choi CG, Yoon S. Body composition, myocardial oxygen uptake and electrocardiogram response in severe obesity with men. Korean Journal of Physical Education. 2002;41:395-405.

35. Shephard RJ, Balady GJ. Exercise as cardiovascular therapy. Circulation. 1999;99:963-972.

36. Kim YJ, Kim CH. Cardiovascular and metabolic responses to the 14 week exercise rehabilitation program in elderly acute coronary syndrome patients. Korean Journal of Measurement and Evaluation in Physical Education and Sport Science. 2010;12:63-71. 